\title{
NÁVRH ELEKTRONICKÉHO SYSTÉMU OZNÁMENIE O ULOŽENÍ ZÁSIELKY PROSTREDNÍCTVOM SMS SPRÁVY.
}

\author{
Tomáš Šimek ${ }^{1}$, Juraj Vaculík ${ }^{2}$
}

\section{Úvod}

Slovenská pošta, a.s. zabezpečuje zber, distribúciu a prepravu správ, informácií a hmotných substrátov v najrôznejšej podobe individuálnou formou pre fyzické a právnické osoby. Táto činnost' sa vykonáva prostredníctvom technologických procesov, ktoré sú výsledkom pôsobenia technických, programových prostriedkov a riadiacej činnosti zamestnancov pošty. Ciel'om návrhu je zlepšenie súčasných služieb poskytovaných Slovenskou poštou implementáciou mobilných elektronických služieb. Navrhujeme možné zlepšenie procesu doručovania zásielok. Konkrétne sa zameriame na proces Oznámenie o uložení zásielky.

\section{Súčasný stav}

V súčasnosti sa situácia na každom type trhu, poštový trh nevynímajúc, vyznačuje vel'kou konkurenciou a stúpajúcimi nárokmi zákazníkov. Kvalita sa v podnikoch netýka len činností, ktoré sa bezprostredne týkajú výrobkov alebo služieb, ale aj celého pozadia, t.j. celého logistického ret'azca a všetkých fáz životného cyklu produktov. Práve kvalita je rozhodujúcim faktorom úspechu každej organizácie a poštové organizácie nie sú výnimkou.

Súčasné spôsoby monitorovania kvality nevyužívajú automatizáciu zberu informácií a spracovanie je tiež vo väčšine prípadov skôr ručné než elektronické. Ručné spracovanie poskytuje vel'ký priestor na chyby a omyly. V elektronickom spracovaní sa vyčlení l'udský faktor a tým pádom aj spomínané chyby, a samozrejme sa celý proces zrýchli (už názov výpočtová technika to zdôvodňuje).

Slovenská pošta doručuje rôzne druhy zásielok. Patria k nim listy a balíky. Listové zásielky sú určené na zasielanie písomností a drobných predmetov, balíkové zásielky sú určené na zasielanie predmetov a vecí. K týmto zásielkam sa poskytujú doplnkové služby.

Doporučené zásielky, zásielky do vlastných rúk, balíky, dobierky a iné sú doručované priamo adresátovi, nevhadzujú sa do poštovej schránky adresáta. Adresát musí potvrdit' prevzatie, prípadne zaplatit’ požadovanú čiastku (dobierka).

\footnotetext{
${ }^{1}$ Mgr. Tomáš Šimek, externý doktorand na Katedre spojov, Fakulta prevádzky a ekonomiky dopravy a spojov, Žilinská univerzita v Žiline, email: tomas.simek@gmail.com,

2 doc. Ing. Juraj Vaculík, PhD., Katedra spojov, Fakulta prevádzky a ekonomiky dopravy a spojov, Žilinská univerzita v Žiline, email: juraj.vaculik@ffpedas.uniza.sk
} 
Takéto zásielky sa pracovník pošty sa pokúsi doručit' adresátovi. Ak je adresát nezastihnutý, do schránky adresáta vloží oznámenie o uložení zásielky. Výnimku tvoria balíky, kde sa prostredníctvom Oznámenia o uložení zásielky, adresátovi oznámi uloženie zásielky na pošte. Doručovatel' vyznačí že sa jedná o balíkovú zásielku.
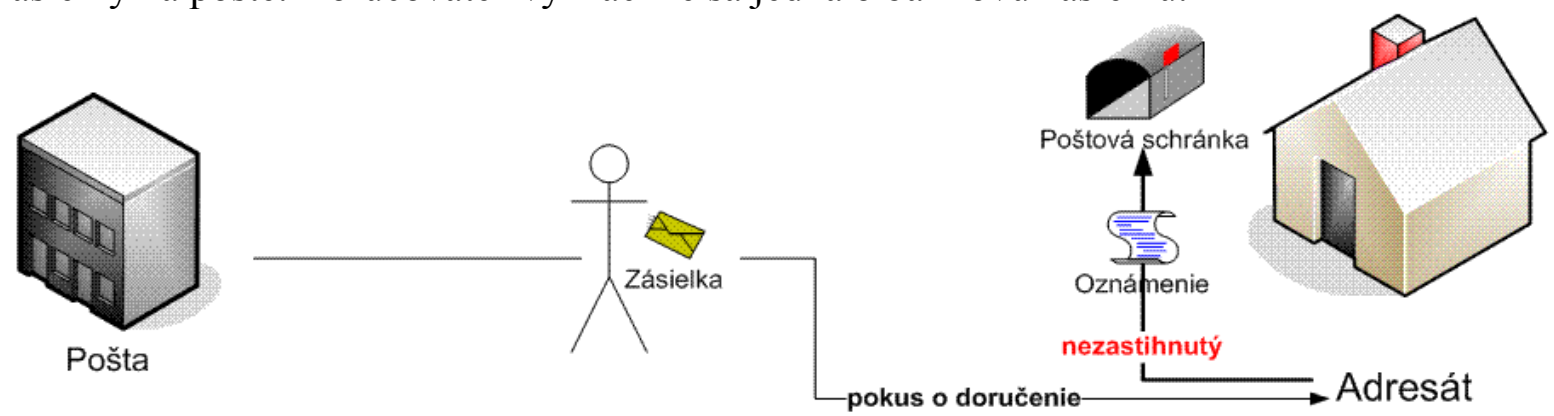

Obr. 1 Doručovanie zásielok s dopInkovými službami

\section{Oznámenie o uložení zásielky SMS správou}

Využitie mobilných telefónov pre účely skvalitnenia poštových služieb sa z hl'adiska ich dostupnosti a rozšírenosti javí ako vhodné riešenie. Penetrácia mobilných služieb bola koncom júna 2007 105,63 \%. Medziročne sa zvýšila o 15,2 percentuálneho bodu. Ku koncu júna evidovali mobilní operátori na Slovensku, Orange Slovensko, T-Mobile Slovensko a Telefonica O2 Slovakia 5,704 milióna zákazníkov. Pokrytie územia a obyvatel’ov Slovenska signálom GSM zobrazuje tabul'ka č. 1 .

\begin{tabular}{|c|c|c|c|c|}
\hline & \multicolumn{2}{|c|}{ Orange } & \multicolumn{2}{|c|}{ T-Mobile } \\
\hline (v \%) & územi & obyvatelia & územ & obyvatelia \\
\hline GSM & 86,8 & 99,3 & 88,1 & 99 \\
\hline EDGE & 62,0 & 87,0 & 36,4 & 71 \\
\hline UMTS & 10,4 & 43,2 & $\mathrm{n} / \mathrm{a}$ & $n / a$ \\
\hline NMT & - & - & $n / a$ & $n / a$ \\
\hline $\begin{array}{l}\text { Flarion (Flash- } \\
\text { OFDM) }\end{array}$ & - & - & 34,8 & 70 \\
\hline
\end{tabular}

Tab. 1 Percentuálne pokrytie územia a obyvatel'stva (n/a = neposkytnutý údaj)

Pre elektronická službu „uloženie zásielky“ navrhujem využit' SMS správy, ktoré sú medzi používatel'mi mobilných telefónov vel'mi obl'úbené a univerzálne využitel'né. Zefektívnenie procesu využitím mobilných elektronických služieb môže priniest' tieto výhody:

- kratšia doba skladovania zásielky - zákazník je prostredníctvom elektronickej služby informovaný o uložení zásielky, potrebné informácie dostane skôr ako doteraz používaných spôsobom

- skvalitnenie služieb pre zákazníkov

- flexibilnost', konkurencie schopnost' - navrhované zlepšenie môže priniest' flexibilnejšie jednanie so zákazníkmi a tým zvýšit' konkurencie schopnost'

- elektronické služby pracujú nepretržite bez ohladu na otváracie hodiny alebo pracovnú dobu 

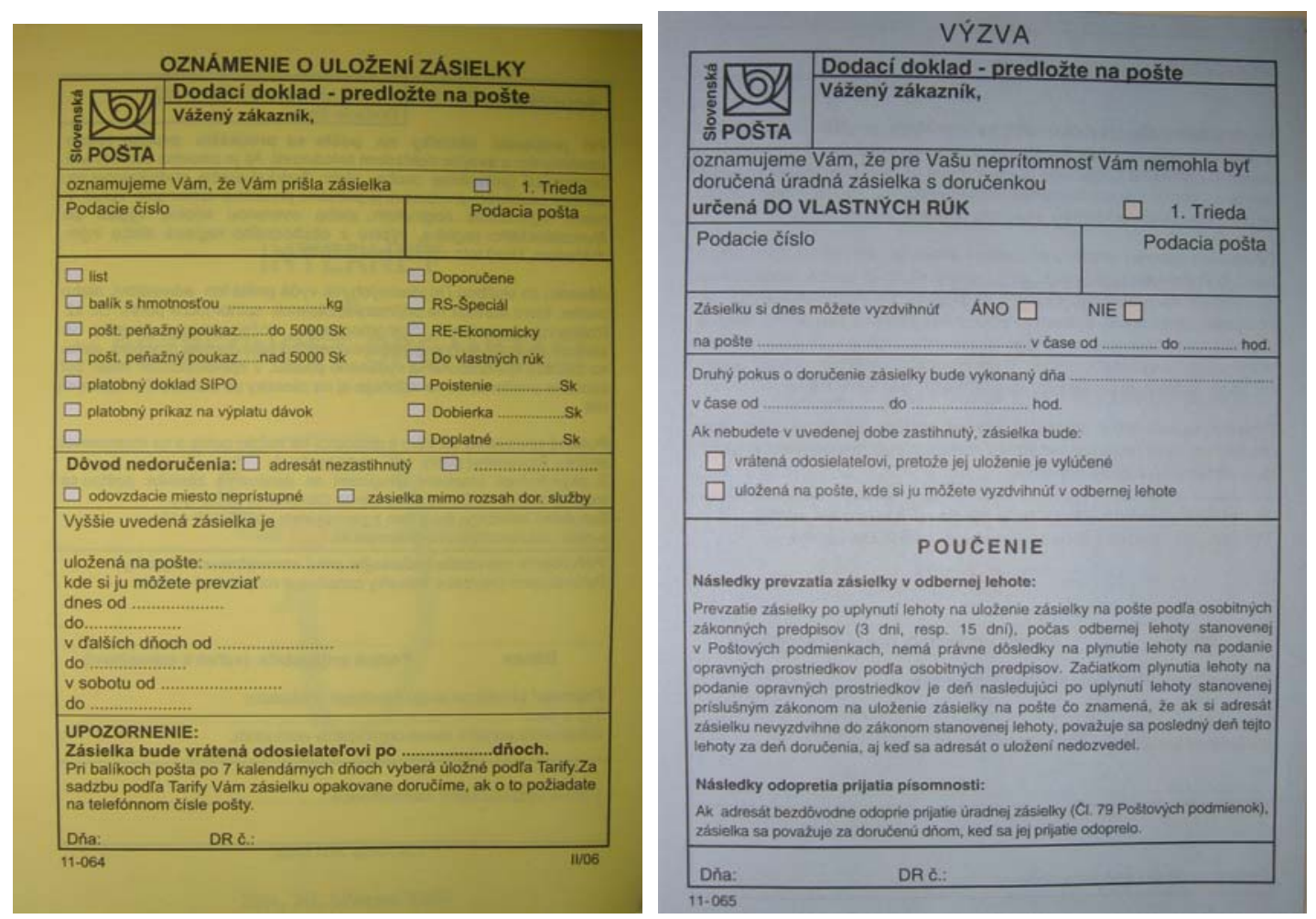

\section{Obr. 2 Tlačivo - oznámenie o uložení zásielky a výzva pri zásielke do vlastných rúk}

Elektronický systém namiesto papierového oznámenia doručí adresátovi SMS správu s informáciou o uložení zásielky, kde a kedy je možné si zásielku prevziat'. Adresát vie o zásielke ihned' po doručení SMS správy a nie až po skontrolovaní poštovej schránky.

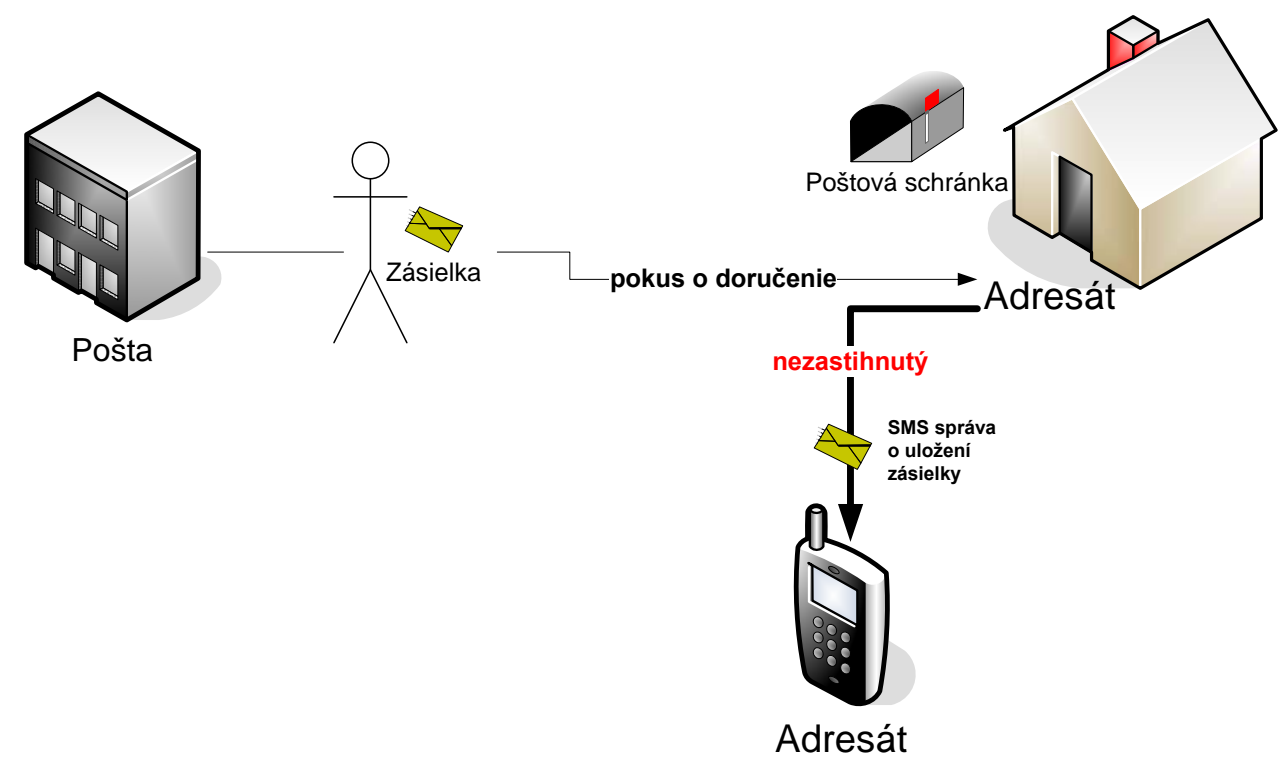

Obr. 3 Popis procesu oznámenia o uložení zásielky prostredníctvom SMS 



Obr. 4 Oznámenie o uložení zásielky SMS správou

\section{Bezpečnostné prvky v prevádzke systému}

Bezpečnost' systémov má prvoradé miesto $\mathrm{v}$ dnešných prudko sa rozvíjajúcich informačných technológiách. Každá spoločnost' je nútená venovat' patričnú pozornost' bezpečnosti informačných systémov nielen pri aplikácii novej technológie, ale aj počas samotnej prevádzky a venovat' vel'kú pozornost' proaktívnej ochrane, pretože ak nastane havarijný stav, môže to znamenat' nemalé straty.

Aplikácia a prevádzka mobilného systému sa skladá z komunikačných prvkov, ktoré prenášajú informácie a tieto informácie je potrebné chránit'. Každý uzavretý systém má miesta, ktoré sú predmetom ochrany. V systéme podobného typu sa tieto prvky vyskytujú na strane mobilnej jednotky, brány do Internetu $\mathrm{z}$ vnútornej siete LAN/WAN SP, a.s., centrálneho servera a samotného dátového prenosu medzi klientom a serverom.

\section{Bezpečnost' na strane mobilnej jednotky}

Mobilná stanica slúžiaca pre odosielanie informácií spracúva dáta, ktoré sú odosielané bud' prostredníctvom SMS správ, alebo dátovou komunikáciou GPRS. Mobilná jednotka je teda vybavená SIM kartou, ktorej je pridelené účastnícke číslo. Bezpečnostným prvkom v mobilnej jednotke je práve pridelené účastnícke číslo, ktorým sa jednotka identifikuje pri komunikácii so serverom centrály. Ked’že komunikácia medzi mobilnou stanicou a serverom centrály môže byt' obojsmerná, je vhodné, aby SIM karta mala aktivovanú službu CLIP (identifikácia volajúceho), čím sa dá zabezpečit' overenie volajúceho prípadne zamedzit' prijímaniu inštrukcií a iných nastavení mobilnej jednotky od iného ako materského aplikačného servera centrály (bližšia architektúra systému v budúcom pokračovaní...).

\section{Literatúra}

[1] http://www.itnews.sk/buxus_dev/generate page.php?page id=49956

[2] http://www.mobilmania.sk

[3] http://www.mobilmania.sk/Operatori/AR.asp?ARI=7331

[4] http://www.slposta.sk

[5] http://www.zss.sk/dokumenty/vyjadrenie.htm 


\section{Grantová podpora}

- MVTS Bil/Nem/SR/ŽU/06 - Pravidlá držiavania sút’aže na trhu elektronických komunikácí́

- VEGA 1/4573/07 - Možnosti, ohraničenia a vývojové tendencie koncepcie univerzálnej služby v pošte a telekomunikáciách v procese globalizácie 